\title{
Teachers Knowledge Of Inclusive Lower Primary Education In Ifako- Ijaiye Local Government Area Of Lagos State, Nigeria
}

\author{
Temitope Funminiyi Egbedeyi \\ National Research University Higher School of Economics, Russian Federation
}

\begin{abstract}
Teachers play a significant role in the process of implementing inclusive lower primary education; however, inclusive education, especially at lower primary, is yet to be fully implemented in Nigeria despite the numerous benefits associated with it. As one of the major implementers of inclusive lower primary, it is imperative to study teachers' knowledge of inclusive lower primary education in IfakoIjaiye, as to provide empirical evidence. Descriptive survey research design was adopted with thirty five (35) teachers who were sampled using simple random. The researcher used "Teachers Knowledge of Inclusive Education Questionnaire (TKLEQ $\alpha=0.92$ ), which was designed by the researcher to collect data. One research question was answered, and two hypotheses were tested at a 0.05 level of significance. Teachers have an average knowledge of inclusive lower primary education (Average Percentage $=53.6$ ). Regular and special teachers have no significant difference on knowledge of inclusive education $(\mathrm{t}=0.50 ; \mathrm{df}=33 ; \mathrm{p}>0.05)$. The recommendation was made according to the findings of the study: it was recommended that Nigerian Government, concerned Non-Governmental Organizations, and Scholars should ensure that regular training is organized for lower primary teachers in order to update their knowledge about inclusive education.
\end{abstract}

Keywords: Inclusive education, Lower primary education; Teachers' knowledge

\section{Introduction}

This is an open access article under the CC-BY-NC license.

The future of any society, group, or nation lies on the shoulders of children, so says an age-long adage, which refers to them as leaders of tomorrow. To assume this position, therefore, they deserve the best form of education, whether informal, formal, or non-formal education, irrespective of their race, gender, colour. It is important to note that education in all ramification is the catalyst of development, thus, since no nation can grow beyond the quality of education delivered to her younger generation, whereas the younger generation is the future of any society (Egbedeyi, 2017).

Education has been viewed from different perspectives, with each scholar attempting a definition to explain a process, which involves the impartation of skills, concepts, and critical information to pupils, with the intention of making them informed and useful to the society they belong to. Adedokun and Olaleye (2014) submit that the best way any nation or society can advanced is to invest in her citizens or people; this investment is known as education, because it is; therefore, education becomes the tool; which communities can employ for nurturing personal growth, that is children and directly culminates into the development of the community (Adedokun \& Olaleye, 2014). Odebiyi (2014) defines education as the transmission of more abstract qualities such as critical thinking skills, healthy living, resilience, and self-confidence that are resident in the older generation to the younger ones. According to the researcher, education can be defined as the transmission of culture, values, and norms of the society to 
the younger generation for the preservation and progress of society's heritage. One of the important things that can be derived from the definition is that education is the right of every child in society.

As part of the efforts of the United Nations toward creating a better environment for children, education was rightly recognized as one of the rights of the children. That is, education becomes essential for children to have not to privilege as documented for the first time Art.26 of The Universal Declaration of Human Rights of the United Nations of 1948 (Struzik, 2014). Also, the Convention on the Rights of the Child of 1989, ratified in Poland in 1991, was divided into two parts (Arts 28 and 30), and the responsibilities of each section were spelled out. For instance: Art.28 targeted free, quality, and equal access to primary education, while Art.29 targeted quality welfare of the child as well as understand and appreciate the uniqueness of other children within his/her locality and around the world (SzczepskaPustkowska, 2009; Struzik, 2014).

Fakolade and Adeniyi (2009) believe that Nigeria government firstly recognized special needs children between the decades of 1970-1980, which was enshrined in the first edition of the Nigeria National Policy on Education, published in the year 1977. However, Omode (2011) discover that inequalities in educational access and achievement, which have contributed to an increase in the number of out-of-school children in Nigeria, which the special needs children are affected the most (Omede 2011 cited in Odebiyi, 2014). The Nigeria population census carried out in the year 2006 gave the number of special people like 3,253, 169 out of which $39 \%$ of these people were school-age children, and this number seems to raise over the years due to many factors (Vanguard Newspaper, 2012). Lucy et al. (2015) identify that the Nigerian constitution makes provision for a suitable education for all children. It is quite disheartening to note that the percentage of enrolled special needs children is $0.42 \%$ out of the $39 \%$ of special age children, the percentage is very poor while compared to their regular counterparts is around 67.05\% (Adetoro, 2014; Lucy et al., 2015).

The deprivation has a traditional undertone, that is before the colonial era, there were very few people with special educational needs since the inured, or severally ill persons eventually met with an early death as adequate medical, education, and other support services were not available (Silwimba, 2011; Odebiyi, 2014). In traditional society, every special needs child is considered sick, which results in reverence and meeting the needs of such children by both immediate and extended family (Wnayi, 2012). They tend to overstress the disability, thus given little chance for special needs children to develop positive self-esteem as well as explores the environment; instead, they receive sympathy rather than empathy (Odebiyi 2014). One of the ways society sympathies with the special needs children to provide a special school named after the particular special needs (Egbedeyi, 2017)

Struzik (2014) explains that segregation becomes relevant because it helped to educate children with special needs in the right environment, such as curriculum revised and specially prepared teachers. After segregation, integration becomes prominent since it allows both special needs and regular children to be within the same school compound, and the origination could be traced to the 1960s (Struzki, 2014). Hulek (1997) explains that an "integrated system of teaching and education consists maximum inclusion of children and teenagers with derivations from standards in public available schools and other institutions as well as allowing them, as far as possible, to develop and learn among healthy peers" (Struzik, 2014).

Maheshwari et al. (2015) find out in Nigeria, the challenges faced by the children with special needs never change, such as discrimination, segregation, and low enrolment in primary school (Nwayi, 2012, Odebiyi, 2014). Therefore in order to forestall the discrimination against the special needs children in the world, especially Nigeria, inclusive education becomes the bride of all the Nations. 
For achieving education for all, inclusive education serves as an avenue for such because it provides an opportunity for all pupils irrespective of their challenges or needs. Adedokun and Olaleye (2014), inclusive education provides a premise where the right to education is upheld; because the provision of quality education becomes paramount to all the stakeholders in order to develop holistic children. Salami and Egbedeyi (2018) believe that inclusive education is necessary for every society that believes in equal and quality education for all citizenry. The implementation of inclusive lower primary education lies on the shoulder of the teachers; being the custodian or facilitator of knowledge and as well the ones who guide the younger generation or pupils to knowledge. Many countries, including Nigeria are making effort to implement inclusive education, yet inclusive education is yet to gain ground in Nigeria (Odebiyi, 2014; Egbedeyi, 2017). Therefore, this study is important as it investigated teachers' knowledge of inclusive lower primary education in Ifako-ljaiye Local Government Area of Lagos State.

\section{Research Question}

One research question was answered in this study.

1. What is the level of teachers' knowledge of inclusive lower primary education in Ifako-ljaiye Local Government Area of Lagos State?

\section{LITERATURE REVIEW}

\section{Teachers' Knowledge Of Inclusive Lower Primary Education}

Asodike and Ikpitibo (2011) state that "primary education is the foundation of formal education". Primary education becomes important no wonder every nation strives to provide quality primary education for her children. It is worth noting that primary education provides an avenue for the receivers to acquire certain skills, which will be useful to the pupils and society. It is important to note that pupils who attend primary education have a higher chance to complete tertiary education and enjoy a good standard of living (Asodike and Ikpitibo, 2011).

The first three years of primary education is tagged as lower primary education, and it is the last cohort of early childhood education. Akinbote (2011) and Oduolowu (2011) note that early childhood education covers from birth to eight plus, and it can be accounted for the largest percentage of development in pupils before age eight. Hence, lower primary education is very important in the lives of pupils as it provides an avenue to correct, adjust and modify any challenge, prepare pupils for the task in life as well as ensure holistic development of pupils is given a priority. Thus, no child should be left behind.

Inclusive education is very important towards providing and educating pupils with or without special needs without any iota of discrimination. The term "inclusion" replaced all previous terminologies, such as integrated special education, reverse mainstreaming in hopes that the word would mean more than placing pupils with special needs in the regular education classroom will aid the holistic developments of both the regular and special need such as a sense of belonging, interpersonal relationship with colleague and teachers, learning (Odom, Buysse and Soukakou, 2011).

The major aim of inclusive education is to eliminate social exclusion, discrimination, and sympathy society has developed for the special needs children, which form as a result of their attitudes, perception, and knowledge as respect for individual child difference or uniqueness (Adetoro, 2014). According to United Nations Children's Fund (UNICEF), 2007, pupils with special needs face discrimination in various means: cultural prejudices often reflect guilt, shame or even fear associated with the birth of a child with a special need., socio-economic, legislative measures, inaccessible environment to children with special needs. Therefore, inclusive education becomes an avenue to tackle all the discrimination, that is, all the educational stakeholders need to work together in order to 
implement inclusive education. One of the most important stakeholders is teachers, the implementer of inclusive education.

The teacher is one of the stakeholders and perhaps the most important one for the success of inclusive education (Sucuoğlu, Bakkaloğlu, Karasu, Demir \& Akalın, 2014). Maheshwari and Shapurkar (2015) state that "a major part of the responsibility for the actualizing of an inclusive system where excellence and equality work in perfect harmony therefore rests in the hands of the teacher". However, teachers need to be aware of the needs of children with special needs, modified the class curriculum with practice, and extra effort are significantly necessary for teachers to impart knowledge in inclusive lower education.

Right information, training, and awareness on the concept of inclusive education are passed to the teachers, and it will develop the teachers' self-confidence about the roles they needed to perform in the classroom (Burke and Shutlerland, 2004; Maheshwari and Shapurkar, 2015). Since lack of knowledge, awareness and skills needed to support children with special needs alongside regular children in a regular classroom is a major barrier as it affect the implementation, influenced teachers' disposition, perceptive and attitude towards inclusive education (Maheshwari and Shapurkar, 2015).

Sucuoğlu et al. (2014), in their findings, report that teachers' lack of knowledge of teaching in inclusive preprimary and elementary classroom, the level of teachers knowledge of children with special needs seemed deficient, thus, their lack of inadequate knowledge is reflected in: assessment and adaptations, supporting language and speech and inclusive classroom management. Sucuoğlu et al (2014) advocate that teachers need to have access to training on inclusive education practices, skills and hands-on training opportunities for working with children with special needs rather than focusing on the teachers' knowledge.

Also, Crane-Mitchel and Hedge (2007), in their study, emphasize that teachers do not understand the features of children with special needs and as well lack knowledge related to meeting these children's needs. Dapudong (2014) reveals that "teachers have moderate knowledge on inclusive education as a way of reducing social discrimination and as integration of Special Educational Needs students in mainstream classrooms yet exhibited partial knowledge on inclusive education as an avenue that can educate all children irrespective of race, creed, gender, and socio-economic status" (Dapudong, 2014).

Inclusive education was introduced in the Nigeria National Policy on Education in 2004, various researchers had carried out studies on inclusive education such as Inclusive education in Nigeria: the Journey so far (Salami, 2013), inclusive education in the 21st century: challenges and opportunities for Nigeria (Garuba, 2003); however, lack of enough or no research studies on the teachers' knowledge of inclusive education; which can serve as the catalyst of ensuring full implementation of inclusive education. Thus, this study aimed at providing empirical evidence on the teachers' knowledge of inclusive lower primary education in Ifako-ljaiye Local Government Area of Lagos State. Ifako-ljaiye, as the research-based, was premised on the availability of primary school, which has inclusive units but failed to practice inclusive education as it supposes to be. The observation has shown that integration was termed as inclusive education. In addition, there are few such schools in the Local Government Area. However, the results from this work can serve as a guideline on what government needs to do in order to ensure full implementation of inclusive education.

\section{Hypotheses}

$\mathrm{H}_{01}$ : There is no significant relationship between teachers' level of education and their knowledge of inclusive education in Ifako-Ijaiye Local Government Area of Lagos State.

$\mathrm{H}_{02}$ : There is no significant difference between special and regular teachers in their knowledge of inclusive education in Ifako-Ijaiye Local Governa ment Area of Lagos State. 


\section{METHODOLOGY}

Aggarwal (2008) "defines descriptive survey research design as devoted to the gathering of information about prevailing conditions or situations for the purpose of description and interpretation". Thus, a descriptive survey research design was used for this study, with the purpose to observe, record, analyze, interpret and describe the knowledge of teachers on inclusive education at lower primary classes as it exists, without any iota of manipulating any variable. The population for this study covered all teachers (regular and special) of the lower primary pupils in Ifako-Ijaye Local Government. The random sampling technique was used to select ten (10) regular primary schools, while total enumeration was used to select the two (2) special schools in Ifako Ijaye Local Government Area of Lagos State. Simple random was used to select 3 lower primary school teachers in both the regular and special schools from the first three classes of the primary school. At the end of the selection, 35 teachers participated in the study. The research instrument used for this study was self-designed titled "Teachers Knowledge of Inclusive Education Questionnaire (TKIEQ)'. The research instrument consisted of two sections. Section A focused on the demographic information of the participants, and Section B measured the teachers' knowledge of inclusive lower primary education, and it contained 14 items which were derived from the literature on a two response scale. The TKIEQ was validated with a split-half technique, which yielded a coefficient of 0.92. The data were analyzed using descriptive statistics of frequency count, percentage, mean, and standard deviation, while inferential statistics of Pearson product-moment correlation and $t-$ test were used to test the hypotheses.

\section{RESULTS AND DISCUSSION}

Data were collected from 35 teachers who fully participated in the study, out of which 29(83\%) teach in regular school, and 6(17\%) teach in a special school.

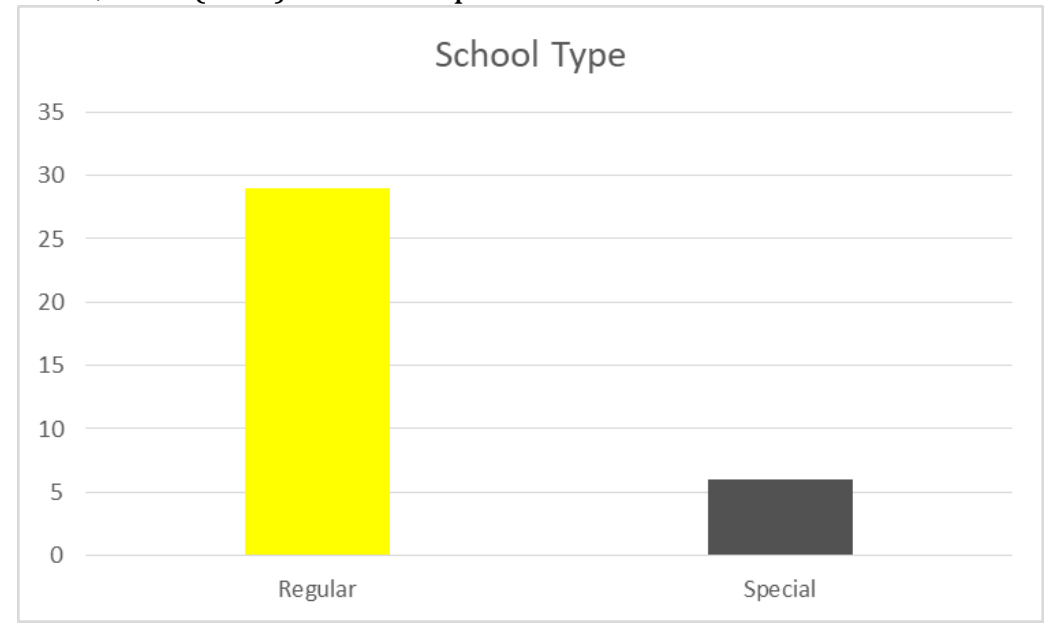

Figure 1: Bar-Chart showing the School type of Teachers

The educational qualifications of the teachers are as follows: $2(6 \%)$ were primary leaving certificate holders, 5(14\%) were SSCE holders, $14(40 \%)$ were degree holders, $12(34 \%)$ were others (certificate) holders, and 2(5.7\%) did not indicate. 


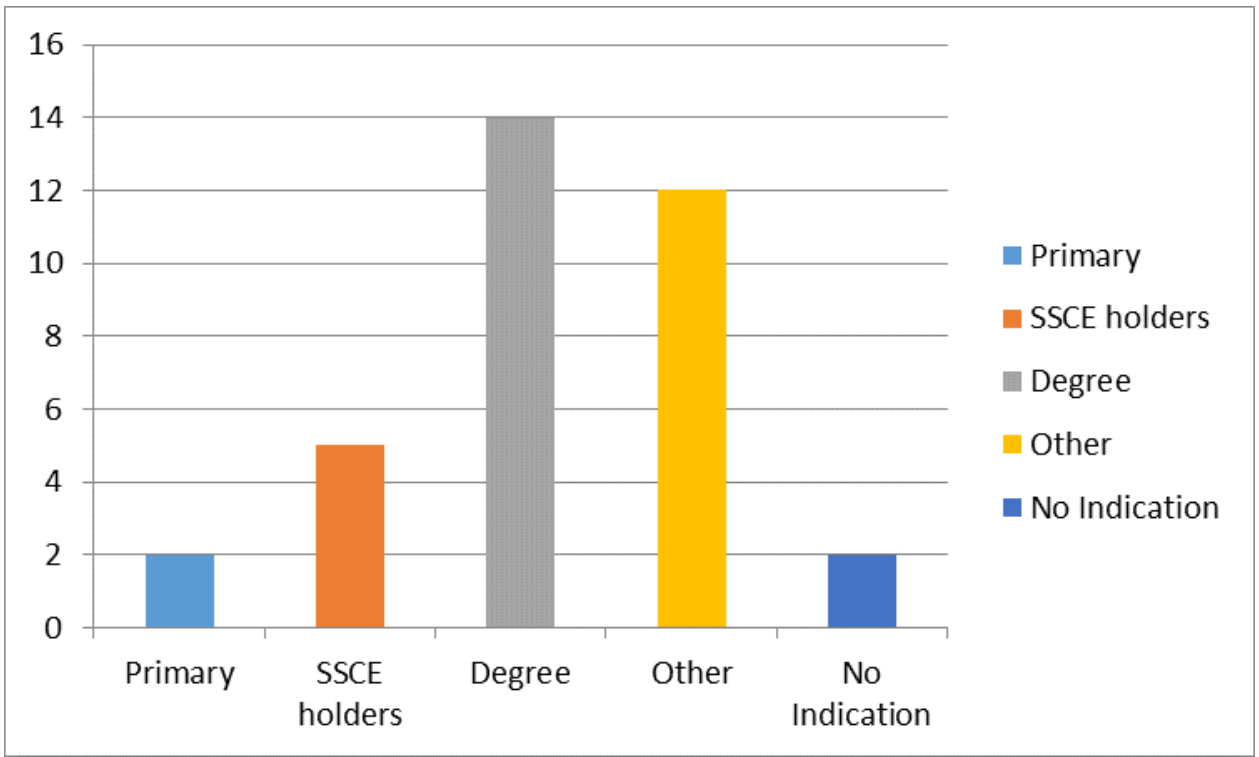

Figure 2: Bar-Chart showing the Educational Qualifications of the Teachers

Research Question 1: What is the level of teachers' knowledge of inclusive lower primary education in Ifako-Ijaiye Local Government Area of Lagos State?

Table 1: Descriptive Statistics of Frequency and Percentage showing the Level of Teachers' Knowledge Inclusive Lower Primary Education

\section{$\mathrm{S} / \mathrm{N} \quad$ ITEM}

1 Inclusive education is hard to maintain in term of assessment, placing children with special needs in the regular classroom

2 Inclusive education encourages teachers to spend quality time with special needs children than their counterpart

3 Inclusive education makes teachers better than any other forms of educational practices

4 Inclusive education protect the right of every child irrespective of their needs or interest

5. Proper training, the good curriculum will help teacher to function well in inclusive education

6 Early identification of the needs of special children will guide teachers to plan learning lessons.

7 Inclusive education put unnecessary pressure on the parents of both children with and without special needs

8. Inclusive education develop leadership skill in the children

9 Learning is easy in inclusive classroom than segregated classroom

10. Inclusive education bridge the gap between regular and special teachers since they are working together under the same roof with the same pupils/children

11. Inclusive education provides special training for teachers to cope 9 with the inclusive classroom

12. Inclusive education brings weariness and tiredness at a very fast pace

FALSE TRUE

$8 \quad 27$

(23)

9

(26)

15

(43)

10

(29)

6

(17)

5

20

25

(14)

9

(26)

21

(60)

22

26

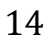

(63)

$17 \quad 18$

(49)

$9 \quad 26$

(31) 


\begin{tabular}{llll}
\hline 13. & Teachers productivity will increase due to inclusive education & 13 & 22 \\
& & $(37)$ & $(63)$ \\
14. & $\begin{array}{l}\text { Necessary learning resources, school infrastructure, and finance } \\
\text { will make inclusive education run smoothly. } \\
\text { Average Percentage= 53.6 }\end{array}$ & 6 & 29 \\
& & $(17)$ & $(83)$ \\
\hline
\end{tabular}

Table 1 shows the level of teachers' knowledge of inclusive lower primary education. The detailed analysis shows that teachers have knowledge of inclusive education that: Early identification of the needs of special children will guide teachers to plan learning lesson (86\%). Proper training, the good curriculum will help teacher to function well in inclusive education(83\%), Necessary learning resources, school infrastructure, and finance will make inclusive education run smoothly(83\%), Inclusive education provide special training for teachers to cope within the inclusive classroom (74\%), Inclusive education protects right of every child irrespective of their needs or interest (71\%), Teachers productivity will increase due to inclusive education (63\%), Inclusive education makes teachers better than any other forms of educational practices (57\%) and Inclusive education bridge gap between regular and special teachers since they are working together under the same roof with the same pupils/children (51\%).

Teachers have no knowledge that: Learning is easy in the inclusive classroom than the segregated classroom (63\%) and Inclusive education develop leadership skill in the children (60\%) were stated in positive term while Inclusive education brings weariness and tiredness at the very fast pace (31\%), Inclusive education put unnecessary pressure on the parents of both children with and without special needs (26\%), Inclusive education encourages teachers to spend quality time with special needs children than their counterpart (26\%), Inclusive education is hard to maintain in term of assessment, placing children with special needs in the regular classroom(23\%) were stated in the negative term. The average percentage of the table is 53.6, which indicates that teachers have an average knowledge of inclusive lower primary education.

This result falls below expectation, which can be deduced as one of the reasons inclusive lower primary education is not fully implemented in Nigeria. This might be as a result of little exposure of the teachers to inclusive education, non-sufficient availability of inclusive lower primary schools in Lagos and Nigeria at large, inaccessible to books on inclusive education, among others. Their lack of adequate knowledge of inclusive lower primary education has an impact on their beliefs and attitude toward it, and also on the implementation. This finding is in support of Sucuoğlu et al. (2014) in their findings report that teachers' lack of knowledge of teaching in inclusive preprimary and elementary classroom, the level of teachers knowledge of children with special needs seemed deficient and the study also supports the finding of Dapudong (2014) reveals that teachers have moderate knowledge on inclusive education as a way of reducing social discrimination and as the integration of Special Educational Needs pupils in the mainstream.

\section{Testing the Null Hypotheses}

Ho1: There is no significant relationship between teachers' levels of education and their knowledge of inclusive education 
Table 2: Summary of Pearson Product Moment Correlation showing the Relationship between Teachers' Level of Education and Knowledge of Inclusive Education

\begin{tabular}{lccccccc}
\hline $\begin{array}{l}\text { Variable } \\
\text { Educational Qualification }\end{array}$ & $\mathrm{N}$ & Mean & Std.D & $\mathrm{r}$ & Sig & Remark \\
& & 2.91 & 1.12 & & & $\begin{array}{l}\text { Not } \\
\text { significant }\end{array}$
\end{tabular}

Knowledge of Inclusive

$8.23 \quad 2.98$

Education

Table 2 shows that there is no significant relationship between teachers' level of education and knowledge of inclusive education ( $\mathrm{r}=0.29 ; \mathrm{P}>0.05)$. Therefore, hypothesis 1 is not rejected. This finding reveals that teachers' level of education has no influence on their knowledge of inclusive education. This could be as a result of the seminar, workshop, and other forms of training which is accessible to the teachers, and also their years of teaching experience might have an impact on their knowledge of inclusive education. This finding support that of Sucuoğlu et al. (2013), who finds out that it is no different in the knowledge level of the teachers and also submit that proper training of teachers will increase their knowledge level. Also, Maheshwari and Shapurkar's (2015) findings show that the teachers' knowledge about the meaning of special needs, types, causes, and intervention was more based on what they have seen around them than the scientific knowledge base. Most of them were not aware of the term "inclusive education.

H02: There is no significant difference between special and regular teachers in their knowledge of inclusive education

Table 3: Summary of t-test Analysis showing the difference between Regular and Special Teachers on Knowledge of Inclusive Education

\begin{tabular}{lccccccc}
\hline $\begin{array}{l}\text { Variable } \\
\text { knowledge of inclusive } \\
\text { education }\end{array}$ & $\mathrm{N}$ & Mean & Std.D & $\mathrm{t}$ & $\mathrm{df}$ & Sig. & Remark \\
Regular & 29 & 8.349 & 3.027 & & & & \\
& & & & 0.502 & 33 & 0.619 & $\begin{array}{l}\text { Not } \\
\text { significant }\end{array}$ \\
Special & 6 & 7.667 & 2.944 & & & &
\end{tabular}

Table 3 shows that there is no significant difference between regular and special teachers on knowledge of inclusive education $(t=0.50 ; d f=33 ; p>0.05)$. Therefore, hypothesis 2 is not rejected. This implies that the school type of teachers has no impact on their knowledge of inclusive education. This might be due to a lack of awareness on inclusive education, and little presence of training which will prepare the teachers with the necessary skills needed to implement inclusive education is not public. This result is in line with Forlin (2001), who suggests that one of the greatest barriers to the development of inclusion is that primary school teachers do not have the required knowledge, skills, and attitudes to carry out this work. Bruns and Mogharberran (2009) are of the opinion teachers at the elementary and preschool level lack adequate preparation to teach children with special needs.

\section{CONCLUSION}

Efforts have been made by Nigerian government in ensuring that inclusive education comes to stay in Nigeria, however, various reasons and challenges such as parental belief and attitude, teacher's 
awareness of inclusion have played significant roles in the implementation of inclusive education in Ifako-ljaiye and Nigeria. As popular axiom "you cannot give what you do not have" this statement is true in Nigeria, as teachers are reluctant in implementing inclusive education due to perceiving stress associated with it. Thus, this study has established that teachers reluctant to implement inclusive lower education is their lack of adequate knowledge about how inclusive education works.

\section{RECOMMENDATIONS}

The following recommendations were made based on the findings of this study: Governments, concerned NGOs, and Scholars should ensure that regular training is organized for the teachers in order to update their knowledge about inclusive education. Both regular and special teachers should be exposed to the same level of training via seminars, workshops, and symposium, due to the fact there is no difference in their knowledge of inclusive education.

\section{REFERENCES}

Adedokun, M.O and Olaleye, F.O. (2014). Inclusive Education and the Development of Nigerian Communities. International Journal of Academic Research in Progressive Education and Development. Vol 3(1). 8-31

Adetoro, R. A. (2014). Inclusive Education in Nigeria-A Myth or Reality? Creative Education Vol 5. Pp 1777- 1781.

Aggarwal, Y.P. (2008). The science of educational Research. Nirmal Book Agency.

Akinbote, O. (2011). Issues in Early Childhood and Primary Education. National Open University of Nigeria

Asodike, J and Ikpitibo, C. L. (2011). Basic issues in primary education delivery in Nigeria. European Scientific Journal. 8(1)

Berger, P. and Luckmann, T. (1966). The social construction of reality. New York: Doubleday

Bruns, A. D., and Mogharberran, C. C. (2009). The gap between beliefs and practices: Early childhood practitioners' perceptions about inclusion. Journal of Research in Childhood Education 21(3): pp 229-241.

Burke, K. and Sutherland, C. (2004). Attitudes towards inclusion: Knowledge vs. Experience. Education 125(2): pp 163-172

Chaula, G. J. (2014). Challenges Teachers Face in Implementation of Inclusive Education in Primary Schools in Tanzania A Case Study of Two Primary Schools in Tanzania. MASTER'S THESIS Hedmark University College

Crane-Mitchel, L., and Hedge, A. V. (2007). Belief and practices of in-service preschool teachers in inclusive settings: Implications for personnel preparation. Journal of Early Childhood Teacher Education 28: pp 353-366.

Dapudong, R. C. (2014). Teachers' Knowledge and Attitude towards Inclusive Education: Basis for an Enhanced Professional Development Program. International Journal of Learning and Development 4(4)

Fakolade, O. A and Adeniyi, S. O. (2009). Attitude of teachers towards the inclusion of special needs children in general education classroom: the case of teachers in some selected schools in Nigeria. International Electronic Journal of Elementary Education 1.3.

Egbedeyi, T. F. (2017). Parents and Teachers' Awareness and Knowledge of Economic and Social Benefits of Inclusive Lower Primary Education and Practices in Ifako-Ijaye Local Government. Unpublished M.Ed Project submitted to Department of Teacher Education, University of Ibadan: ix- 100

Garuba, A. (2003). Inclusive Education on the 21st Century. Challenges and Opportunities for Nigeria. Asia Pacific Disability Rehabilitation Journal Vol. 14 (2). 
Hulek, A. (1997. Pedagogika rewalidacyjna (Revalidation pedagogy,), Warszawa: PWN.

Lucy A. E., Ezekiel O and John, A. O. (2015). Challenges Facing Implementation of Inclusive Education in Public Secondary Schools in Rongo Sub- County, Migori County, Kenya, IOSR Journal of Humanities and Social Science (IOSR-JHSS) 20.4: 39-50.

Maheshwari, P and Shapurkar, M. (2015). Awareness and Attitudes of Primary Grade Teachers (1-4thGrade) towards Inclusive Education, International Scholarly and Scientific Research and Innovation 9(11): 3873-3878

Odebiyi, O. M. (2014). Pre-Primary and Primary School Teacher Perception of and Attitude towards Inclusive Education in Ibadan. Unpublished Dissertation. Submitted to the University of Ibadan.

Odom, S.L., Buysse, V., and Soukakou, E. (2011). Inclusion for Young Children with Disabilities: A Quarter Century of Research Perspectives, Journal of Early Intervention 33.4: 344-356.

Oduolowu, E. (2011). Contemporary issues in early childhood education. Ibadan: Franco-Ola Publishers.

Omede, A.A. (2011). Reforms in special education for optimum educational attainment by person with special needs for national development. Journal of Merging Trends in Educational Research and Policy Studies 2.4:296-300.

Szczepska-Pustkowska, M. (2009). Prawa dziecka, W: D. Klus-Stańska, M. SzczepskaPustkowska (Red.), Pedagogika wczesnoszkolna - dyskursy, problemy, rozwiązania. Warszawa: Wydawnictwo Akademickie i Profesjonalne (Rights of the child, D. Klus-Stańska, M. Szczepska-Pustkowska (Red.), Early school pedagogy - discourses, problems, solutions. Warsaw: Academic and Professional Publishing House).

Salami, I.A. (2013). Inclusive early childhood education in Nigeria: the journey so far. The Journal of International Association of Special Education Vol 15(2): 118-126.

Salami, I.A and Egbedeyi, T.F. (2018). Inclusive Lower Primary Education: Parents' Awareness of the Economic and Social Benefits. Journal of Positive Psychology and Counselling Vol 2 (1) pp 33-45

Struzik, A. (2014). Different ways to individual success of a pupil - from segregation to inclusion in The paradigm of inclusive education in theory and practice edited by Zdzisława Zacłona and Ivica Radovanović. Nowy Sącz pp 9-17

Sucuoğlu, B., Bakkaloğlu, H., Karasu, F. İ., Demir, Ş., and Akalın, S. (2014). Inclusive Preschool Teachers: Their Attitudes and Knowledge about Inclusion. International Journal of Early Childhood Special Education (INT-JECSE) 5.2: 107-128.

UNICEF (2007). Promoting the Rights of Children with Disabilities, UNICEF, Florence. 


\section{APPENDIX}

\section{TEACHERS' KNOWLEDGE OF INCLUSIVE EDUCATION QUESTIONNAIRE (TKIEQ)}

Dear Teacher,

This instrument is designed to obtain information on the knowledge of inclusive education in Ifako-Ijaye Local Government. The information collected is purely for academic purpose and such information provided will be treated with utmost confidentiality. Therefore, kindly feel free to answer the questions without any reservation.

Thank you

\section{SECTION A: DEMOGRAPHIC INFORMATION}

Gender: Male ( ) Female ( )

Educational Qualification: Primary leaving certificate ( ) SSCE ( ) Degree/HND ( ) others ( ) -------

School type: regular ( ) special school ( )

Teaching Experience: 1-5years ( ) 6-10years ( ) 11-15years ( ) 16-20years ( ) 20 years and above ( )

\section{SECTION B: KNOWLEDGE OF INCLUSIVE EDUCATION PRACTICES}

Kindly indicate the extent to which you agree or disagree with the following items by ticking FALSE OR TRUE

\begin{tabular}{|c|c|c|c|}
\hline $\mathbf{S} / \mathbf{N}$ & ITEM & FALSE & TRUE \\
\hline 1 & $\begin{array}{l}\text { Inclusive education is hard to maintain in term of assessment, } \\
\text { placing children with special needs in the regular classroom }\end{array}$ & & \\
\hline 2 & $\begin{array}{l}\text { Inclusive education encourage teachers to spend quality time with } \\
\text { special needs children than their counterpart }\end{array}$ & & \\
\hline 3 & $\begin{array}{l}\text { Inclusive education makes teachers better than any other forms of } \\
\text { educational practices }\end{array}$ & & \\
\hline 4 & $\begin{array}{l}\text { Inclusive education protect right of every child irrespective of their } \\
\text { needs or interest }\end{array}$ & & \\
\hline 5. & $\begin{array}{l}\text { Proper training, good curriculum will help teacher to function well } \\
\text { in inclusive education }\end{array}$ & & \\
\hline 6 & $\begin{array}{l}\text { Early identification of needs of special children will guide teachers } \\
\text { to plan learning lesson. }\end{array}$ & & \\
\hline 7 & $\begin{array}{l}\text { Inclusive education put unnecessary pressure on the parents of } \\
\text { both children with and without special needs }\end{array}$ & & \\
\hline 8. & Inclusive education develop leadership skill in the children & & \\
\hline 9 & Learning is easy in inclusive classroom than segregated classroom & & \\
\hline 10. & $\begin{array}{l}\text { Inclusive education bridge gap between regular and special } \\
\text { teachers since they are working together under the same roof with } \\
\text { the same pupils/children }\end{array}$ & & \\
\hline 11. & $\begin{array}{l}\text { Inclusive education provide special training for teachers to cope } \\
\text { within the inclusive classroom }\end{array}$ & & \\
\hline 12. & $\begin{array}{l}\text { Inclusive education bring weariness and tiredness at the very fast } \\
\text { pace }\end{array}$ & & \\
\hline 13. & Teachers productivity will increase due to inclusive education & & \\
\hline 14. & $\begin{array}{l}\text { Necessary learning resources, school infrastructure and finance will } \\
\text { make inclusive education run smoothly. }\end{array}$ & & \\
\hline
\end{tabular}

